\title{
Peningkatan Effisiensi Elektrik Modul Surya Menggunakan Bahan Berubah Fasa dan Maximum Power Point Tracking (MPPT)
}

\author{
Fery Hidayat $^{1}$, Yuli Setyo Indartono ${ }^{2}$, Aryadi Suwono ${ }^{2}$ \\ ${ }^{1}$ Institut Teknologi Nasional Bandung, ${ }^{2}$ Institut Teknologi Bandung \\ Email: feryhidayat06@gmail.com
}

\begin{abstract}
ABSTRAK
Pemanfaatan Modul Surya (Photovoltaic-PV) untuk membangkitkan daya elektrik terkendala oleh efisiensi yang masih rendah. Efisiensi elektrik tersebut juga akan turun seiring dengan peningkatan temperatur sel PV selama PV beroperasi. Penggunaan Crude Palm Oil (CPO) sebagai bahan berubah fasa (Phase Change Material-PCM) bertujuan untuk menghambat kenaikan temperatur sel-PV, sedangkan untuk mendapatkan daya maksimum dengan menggunakan Maximum Power Point Tracking (MPPT). Jurnal ini memuat hasil pengujian penggunaan PCM dan MPPT untuk meningkatkan efisiensi elektrik PV, dan dari hasil pengujian menunjukkan bahwa kombinasi antara PCM dan MPPT pada PV mampu meningkatkan efisiensi PV secara sigifikan dari 9,64\% menjadi 16,27\%.
\end{abstract}

Kata kunci: Modul surya (PV), Bahan Berubah Fasa (PCM), Maximum Power Point Tracking (MPPT).

\begin{abstract}
Utilization of Photovoltaic-PV to generates electric power is constrained by low efficiencies of the PV system. The electrical efficiensies will decrease by increasing PV cells temperature during operations. Crude Palm Oil as Phase Change Material (PCM) are used to prevent temperature rising of PV cells, wherease to get the maximum power of $P V$ by using Maximum Power Point Tracking (MPPT). This journal coutains the result of testing the use of PCM and MPPT can improve electrical efficienciy of PV, and from the test result showed used both PCM and MPPT on PV is able to improve electrical efficiency around $9.64 \%$ to $16.27 \%$.
\end{abstract}

Keywords: Photovoltaic-P), Phase Change Material (PCM), Maximum Power Point Tracking (MPPT). 


\section{PENDAHULUAN}

Pemanfaatan energi fosil dalam memenuhi kebutuhan energi dunia berkisar diangka $80 \%$ dibandingkan dengan sumber energy lainnya. Dampak negatif pemanfaatan energi fosil terhadap lingkungan serta sifat tidak terbarukan dari energi jenis ini mendorong berbagai penelitian untuk menemukan sumber energi baru dan terbarukan. Salah satu bentuk energi baru dan terbarukan adalah pemanfaatan energi surya.

Negara Kesatuan Republik Indonesia (NKRI) terletak pada $6^{\circ} \mathrm{LU}-11^{\circ} \mathrm{LS}$ dan $95^{\circ}-141^{\circ} \mathrm{BT}$ memiliki intensitas iradiasi matahari tahuhan rata-rata $4,8 \mathrm{kWh} / \mathrm{m}^{2} /$ hari[1],dimana peluang pemanfaatan energi surya ini dengan menggunakan Sel Photovoltaic (PV). Namun harga investasi untuk suatu sistem PV masih relatif mahal dan terkendala oleh efisiensi elektriknya masih kecil yaitu pada interval $17-20 \%$ serta penurunan efisiensi PV seiring meningkatnya temperatur PV. Pada PV hanya sekitar 13-16\% iradiasi matahari yang diubah menjadi listrik, sisanya terbuang sebagai panas. Iradiasi matahari menaikkan temperatur PV serta menurunkan efisiensi konversi energi dari energi matahari menjadi listrik sebesar 0,4\%-0,5\% $\mathrm{K}^{-1}$. Pengujian independen suatu PV "BP Saturn" menunjukkan penurunan efisiensi konversi daya listrik dari sebesar $15,8 \%$ pada $25^{\circ} \mathrm{C}$ menjadi $12 \%$ pada $80^{\circ} \mathrm{C}$ [2]. Pemanfaatan teknologi PCM dapat dijadikan pilihan untuk menghambat kenaikan temperature PV pada saat operasi puncak PV sehingga penurunan efisiensi modul PV juga dapat dihambat.

Crude Palm Oil (CPO) termasuk jenis PCM organik karena memiliki susunan fatty acids. Dari suatu percobaan terhadap lima sampel CPO, diketahui memiliki densitas $0,909 \mathrm{~g} / \mathrm{mL}-0,917 \mathrm{~g} / \mathrm{mL}$ pada temperatur $25 \mathrm{oC}$ dan $0,888 \mathrm{~g} / \mathrm{mL}-0,891 \mathrm{~g} / \mathrm{mL}$ pada temperatur $55^{\circ} \mathrm{C}$. Titik leleh CPO berada pada interval temperatur $38,52^{\circ} \mathrm{C}-39,78^{\circ} \mathrm{C}$, titik kristalisasi $\mathrm{CPO}$ berkisar antara temperatur $21,12^{\circ} \mathrm{C}-$ $23,55^{\circ} \mathrm{C}[4]$.

\section{METODOLOGI PENELITIAN}

Tahapan kegiatan penelitian ini Penulis mengumpulkan informasi tentang PV, MPPT, serta PCM dari buku, jurnal dan hasil penelitian. Selanjutnya Penulis merancang instalasi PV, instalasi PV yang menggunakan PCM, MPPT serta instalasi PV kombinasi PCM dan MPPT, kemudian akan dilakukan tahapan pengujian.

Pada pengujian instalasi PV, Penulis mengumpulkan besaran output PV berupa arus-tegangan (I-V), juga dilakukan pengukuran temperature permukaan atas dan permukaan bawah PV serta iradiasi matahari. Tahapan analisis dilakukan dengan mengolah data besaran ouput PV untuk menghitung daya dan efisiensi elektrik PV, PV/PCM, PV/MPPT, PV/PCM dan MPPT. Pengolahan data hasil pengukuran dilaksanakan menurut Skema proses pengolahan data keluaran modul PV (Gambar.1). Analisis juga dilakukan terhadap fenomena-fenomena yang berkaitan dengan hubungan temperature dengan iradiasi, daya, dan efisiensi elektrik PV yang terjadi selama berlangsungnya tahapan pengujian instalasi PV.

Tahapan penarikan kesimpulan dilakukan Penulis dengan membandingkan kenaikan efisiensi yang dicapai oleh PV-PV/PCM, PV-PV/MPPT dan PV-PV/PCM dan MPPT, serta keterkaitan fungsi antara PCM dan MPPT. 


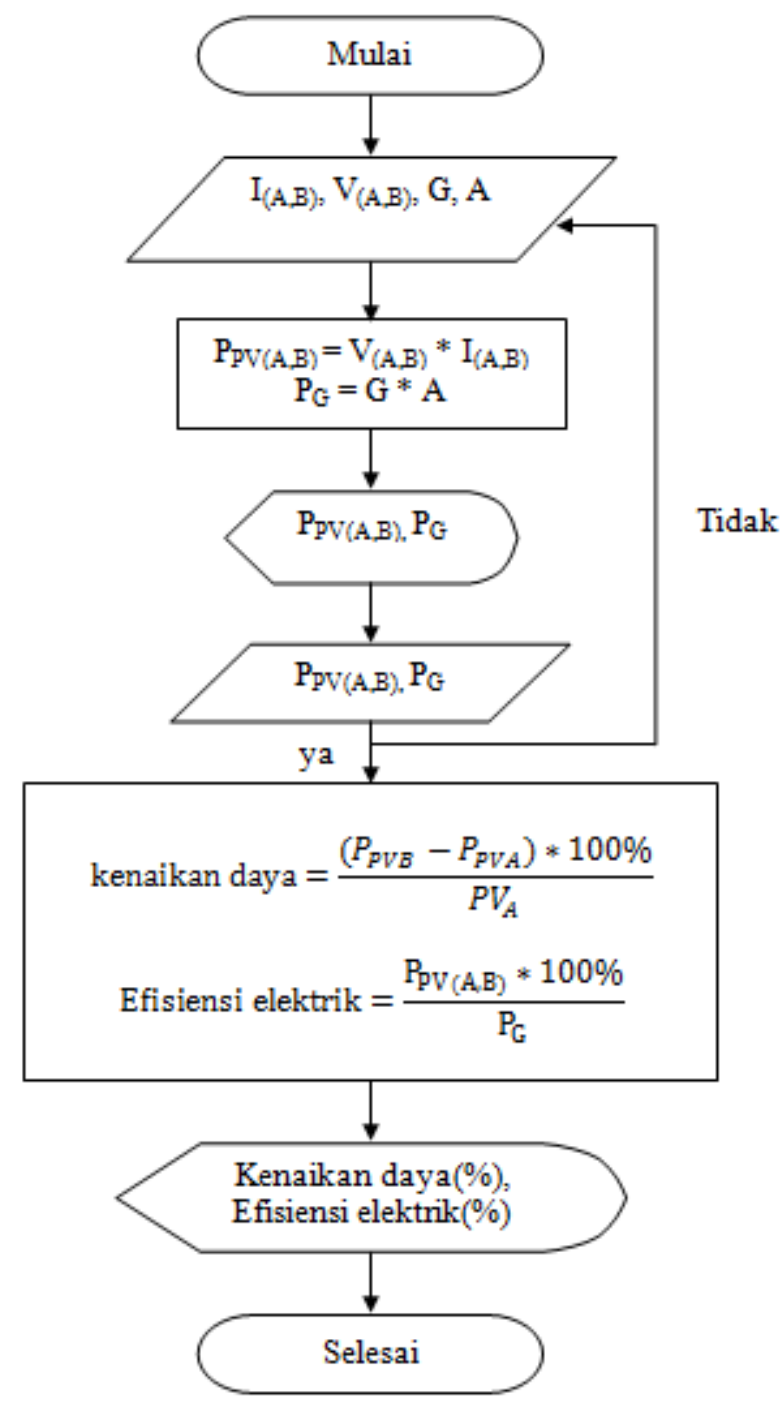

Gambar 1. Skema proses pengolahan data keluaran modul PV.

\section{ALAT DAN BAHAN}

Pemilihan Crude Palm Oil (CPO) sebagai PCM karena memenuhi kriteria sebagai berikut:

1. Harga CPO relatif murah dan mudah didapatkan di Indonesia.

2. Titik leleh, densitas, panas spesifik dan konduktivitas termal CPO cukup tinggi.

3. Crude Palm Oil (CPO) merupakan bahan organik sehingga ramah lingkungan.

Modul Surya (PV) yang digunakan berjumlah dua buah, jenis monocrystalline tipe SMI 10-50 berkapasitas $50 \mathrm{Wp}$.

Tabel 1. Spesifikasi Teknis Modul Surya SMI 10-50.

\begin{tabular}{lc}
\hline Type & SMI 10-50 \\
\hline Maximum Power (Pmax) & $50 \mathrm{Wp}$ \\
\hline $\begin{array}{l}\text { Maximum Power Voltage } \\
\text { (Vmp) }\end{array}$ & $21,8 \mathrm{~V}$ \\
\hline Maximum Power Current (Imp) & $2,29 \mathrm{~A}$ \\
\hline Open Circuit Voltage (Voc) & $26,60 \mathrm{~V}$ \\
\hline Open Circuit Current (Isc) & $2,65 \mathrm{~A}$ \\
\hline Maximum system voltage & $1000 \mathrm{~V}$ \\
\hline
\end{tabular}


Controller yang digunakan adalah sebuah Morningstar's Tristar controller tipe TS 45 dan Morningstar SunSaver controller tipe SS-MPPT-15L, serta sebuah multimeter tipe Heles UX-369, pengukuran iradiasi matahari dengan menggunakan Solar Power Meter Tenmars tipe TM-206.

Pengukuran temperatur modul surya dengan menggunakan Temperature data acquisition device OM$D A Q-U S B-2400$ Series dengan 8 Channel termokopel sehingga pengukuran modul surya dapat dilakukan pada waku yang sama.

\section{PENGUJIAN}

\subsection{Pemilihan Termokopel Tipe-K}

Sebelum pengujian terhadap modul surya, dilakukan proses kalibrasi termokopel tipe K dengan menggunakan TRH central sebagai kalibrator.

Tabel 2. Selisih Pembacaan Temperatur Termokopel Tipe-K terhadap TRH central.

\begin{tabular}{|c|c|c|c|c|c|c|c|c|}
\hline $\begin{array}{l}\text { Tipe K } \\
\left( \pm{ }^{\circ} \mathrm{C}\right)\end{array}$ & $\begin{array}{l}\mathrm{T} 1 \\
\left({ }^{\circ} \mathrm{C}\right) \\
\end{array}$ & $\begin{array}{l}\mathrm{T} 2 \\
\left({ }^{\circ} \mathrm{C}\right) \\
\end{array}$ & $\begin{array}{l}\mathrm{T3} \\
\left({ }^{\circ} \mathrm{C}\right) \\
\end{array}$ & $\begin{array}{r}\mathrm{T4} \\
\left({ }^{\circ} \mathrm{C}\right) \\
\end{array}$ & $\begin{array}{l}\mathrm{T} 5 \\
\left({ }^{\circ} \mathrm{C}\right) \\
\end{array}$ & $\begin{array}{l}\text { T6 } \\
\left({ }^{\circ} \mathrm{C}\right) \\
\end{array}$ & $\begin{array}{c}\text { T7 } \\
\left({ }^{\circ} \mathbf{C}\right)\end{array}$ & $\begin{array}{r}\text { T8 } \\
\left({ }^{\circ} \mathrm{C}\right) \\
\end{array}$ \\
\hline $\begin{array}{l}\text { TRH } \\
\left({ }^{\circ} \mathbf{C}\right)\end{array}$ & 0,37 & 0,34 & 0,28 & 0,26 & 2,10 & 1,99 & 1,19 & 1,26 \\
\hline
\end{tabular}

Dari Tabel 2 di atas maka termokopel yang akan digunakan dalam pengujian adalah T1, T2, T3, T4 dan T7.

\subsection{Pengukuran massa padat Crude Palm Oil (CPO)}

Pengukuran massa padat bertujuan untuk mengetahui titik leleh dari CPO. hasil pengukuran massa padat CPO dapat dilihat pada grafik massa padat CPO.

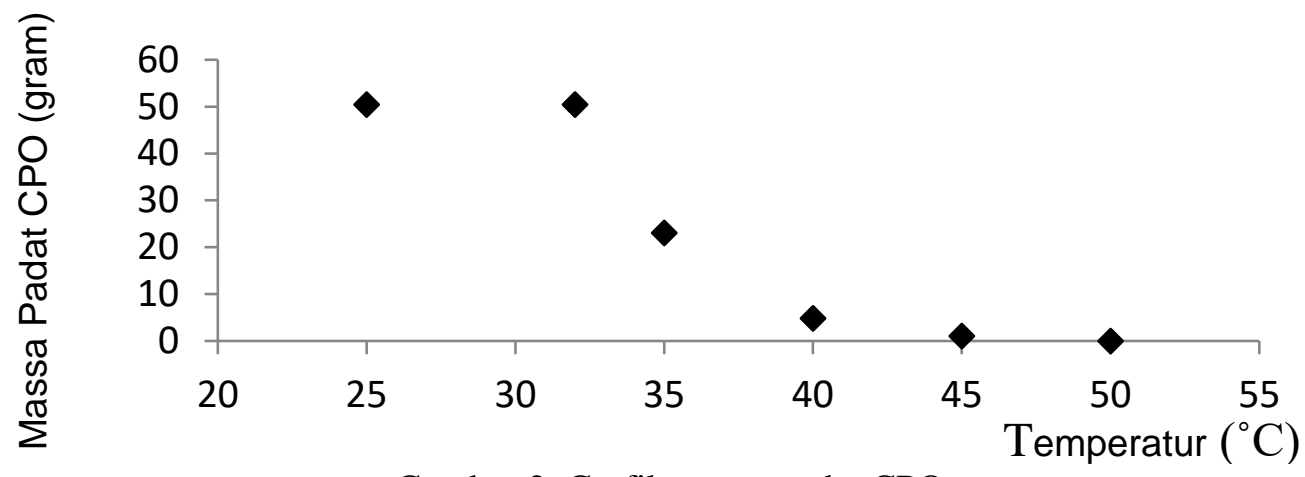

Gambar 2. Grafik massa padat CPO.

Berikut ini adalah massa padat CPO pada berbagai tingkatan temperatur.

Tabel 3. Massa padat CPO pada berbagai tingkatan temperatur (T).

\begin{tabular}{ccccccc}
\hline \multirow{2}{*}{ CPO } & \multicolumn{6}{c}{ Temperatur $\left({ }^{\circ} \mathrm{C}\right)$} \\
\cline { 2 - 7 } & 25 & 32 & 35 & 40 & 45 & 50 \\
\hline $\begin{array}{c}\text { Sisa massa } \\
\text { padat (gr) }\end{array}$ & 50,427 & 50,427 & 23,045 & 4,855 & 1,036 & 0 \\
\hline $\begin{array}{c}\text { Sisa massa } \\
\text { padat (\%) }\end{array}$ & 100 & 100 & 45,700 & 9,628 & 2,054 & 0 \\
\hline
\end{tabular}




\subsection{Instalasi Pengujian Modul surya}

Pengujian menggunakan dua buah Modul surya, Modul surya A dan Modul surya B. Bagian belakang Modul Surya A tidak menggunakan PCM sedangkan pada Modul surya B dipasang PCM (CPO) yang diisikan dalam rectangular tube berukuran 1" $\mathrm{x}$ 1,5" dan dipasang dibagian permukaan belakang Modul surya B.

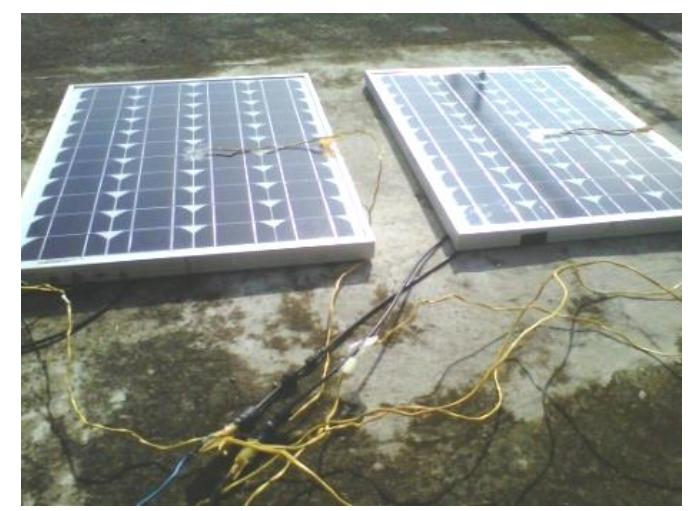

Gambar 3. Instalasi pengujian Modul surya.
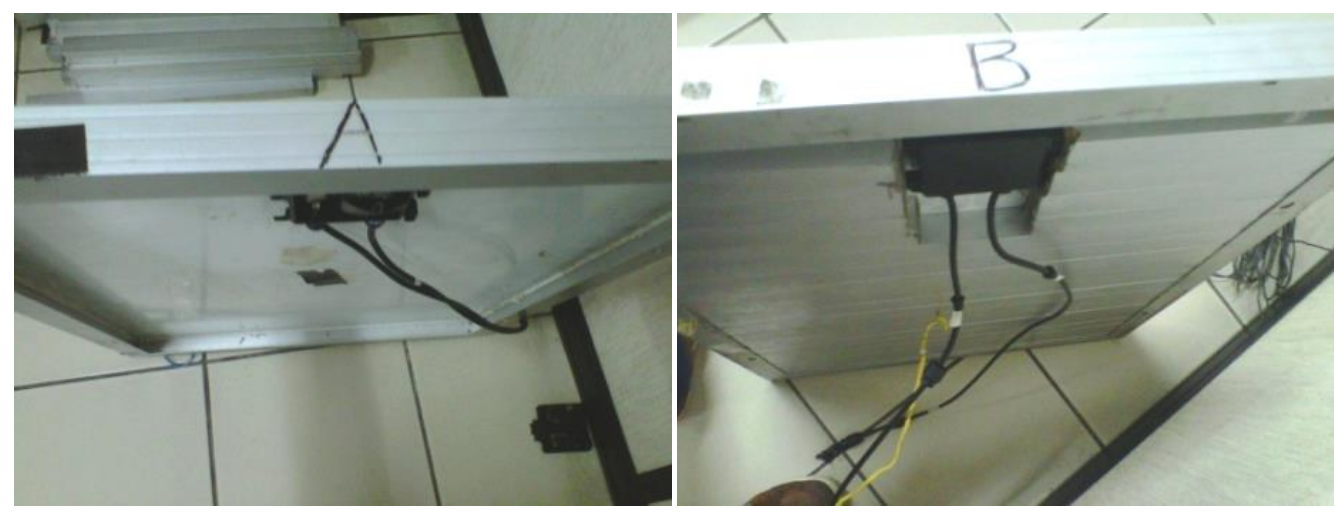

Gambar 4. Pemasangan PCM pada Modul surya.

\section{HASIL DAN PEMBAHASAN}

Pengujian modul surya A dengan modul surya B yang menggunakan PCM hasil terlihat pada gambar, kenaikan iradiasi matahari akan diikuti kenaikan temperatur sel PV. Pada Modul surya B, kenaikan temperatur dihambat akibat panas permukaan sel PV sebagian besar diserap oleh PCM, hal ini dilihat pada Modul surya B temperatur terukur selalu lebih rendah dari Modul surya A. Saat temperatur PCM mencapai $50^{\circ} \mathrm{C}$, penyerapan menjadi tidak efektif karena PCM sudah berubah fasa menjadi cair $100 \%$ yaitu pada nilai iradiasi mencapai $1037 \mathrm{~W} / \mathrm{m}^{2}$ dan temperatur $57^{\circ} \mathrm{C}$, terlihat kurva temperatur Modul surya B memotong kurva temperatur Modul surya A.

Respon PCM terhadap penurunan iradiasi yang berlangsung cepat dan tiba-tiba sangat lambat, hal ini diakibatkan karena PCM memiliki inersia termal yang tinggi sehingga ketahanan untuk mempertahankan temperaturnya juga tinggi. Namun pada saat iradiasi naik secara cepat dan tiba-tiba kembali turun, karena sifat yang sama PCM akan memperlambat kenaikan temperatur permukaan PV. Respon PCM terhadap penurunan iradiasi yang berlangsung cepat dan tiba-tiba sangat lambat, hal ini diakibatkan karena PCM memiliki inersia termal yang tinggi sehingga ketahanan untuk mempertahankan temperaturnya juga tinggi. Namun pada saat iradiasi naik secara cepat dan tiba-tiba kembali turun, karena sifat yang sama PCM akan memperlambat kenaikan temperatur permukaan PV. 


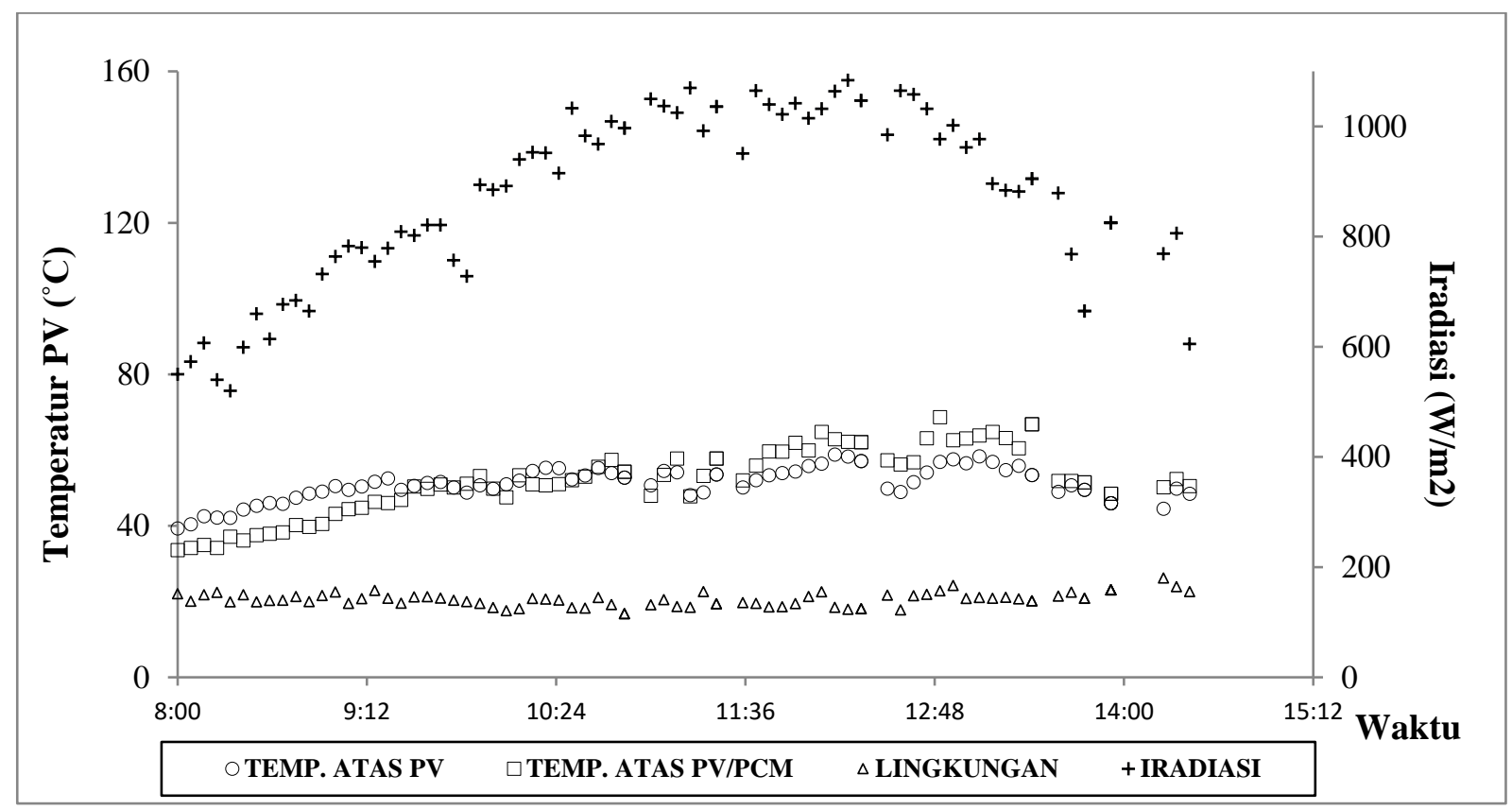

Gambar 5. Grafik temperatur permukaan atas dan iradiasi Matahari PV dan PV/PCM.

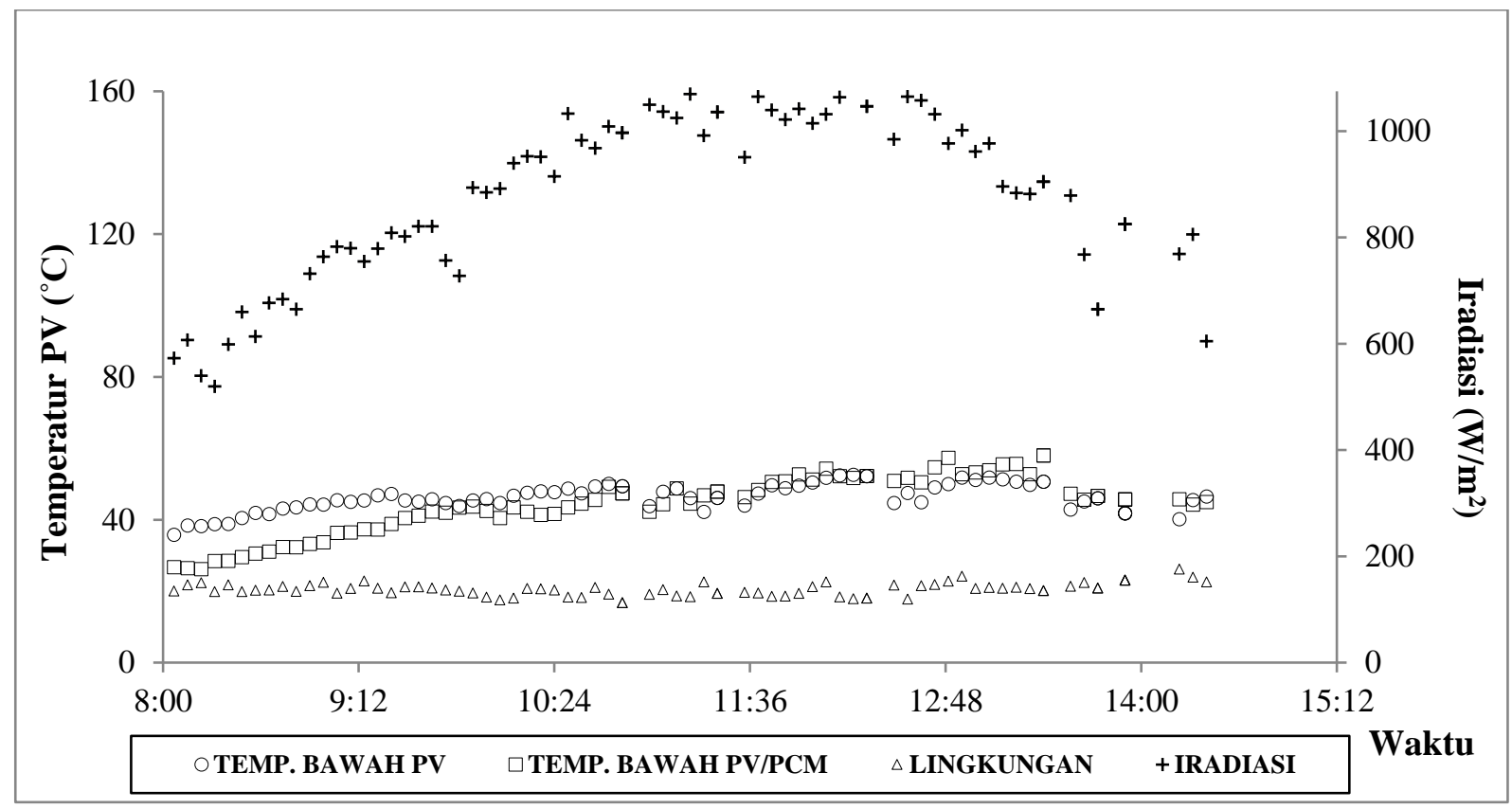

Gambar 6. Grafik temperatur permukaan bawah PV dan PV/PCM serta iradiasi Matahari.

Daya elektrik Modul surya B selalu lebih tinggi dari Modul surya A. Hal ini karena PCM bekerja efektif dalam menghambat kenaikan temperatur permukaan PV. Pada saat terjadi penurunan iradiasi tiba-tiba dan berlangsung sangat cepat terlihat daya kedua Modul surya turun mengikuti turunnya iradiasi, pada saat hal ini terjadi, daya kedua Modul surya bernilai hampir sama. Selisih daya yang mengecil antara Modul surya B dengan Modul surya A dapat disebabkan karena pengaruh inersia termal yang dimiliki CPO. penggunaan PCM pada Modul surya B tercatat dapat menghasilkan kenaikan daya elektrik rata-rata sebesar $20,94 \%$. Selain itu juga meningkatkan efisiensi elektrik ratarata dari $6,42 \%$ menjadi $7,72 \%$. 


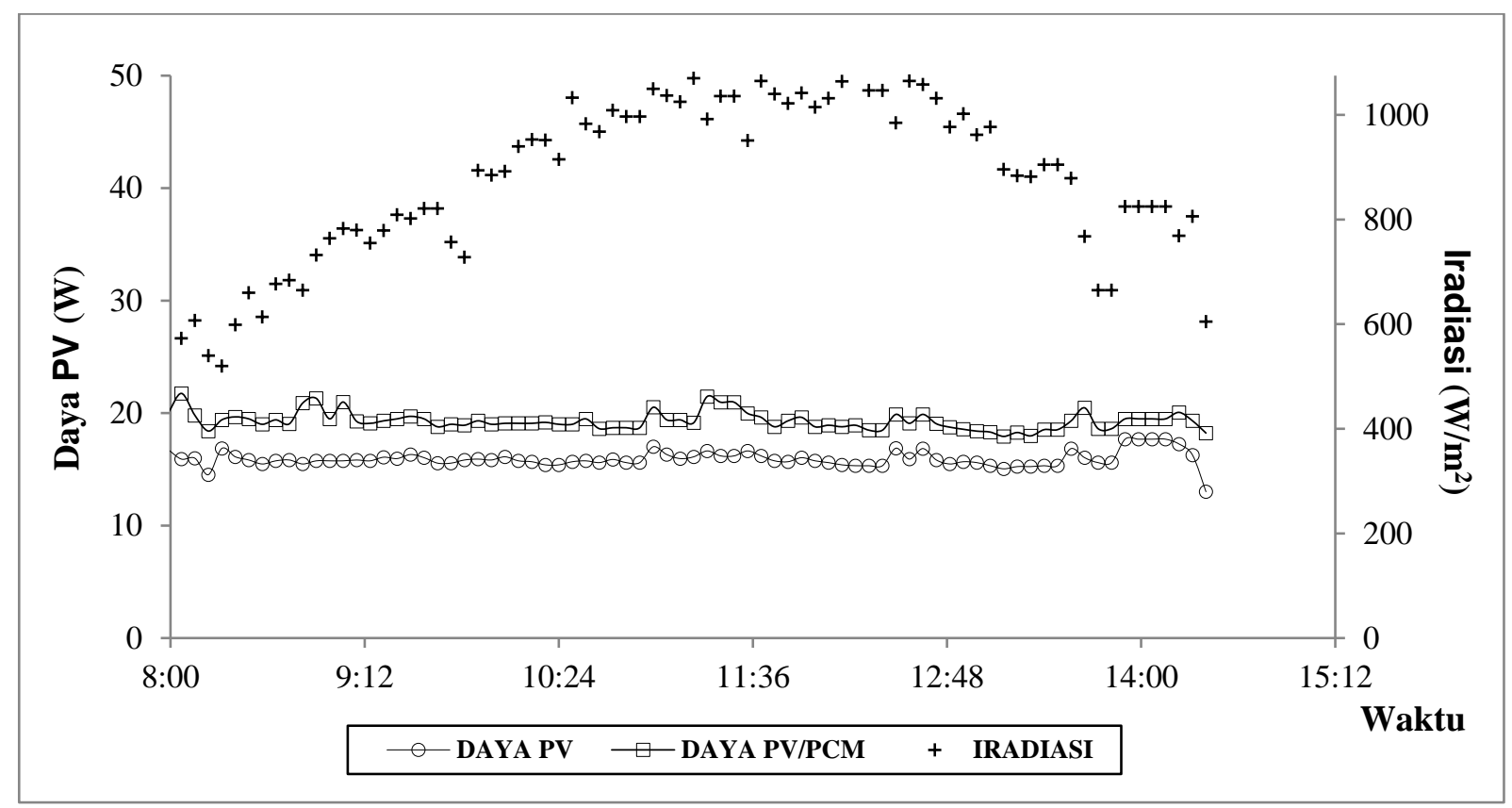

Gambar 7. Grafik daya PV dan PV/PCM serta iradiasi matahari.

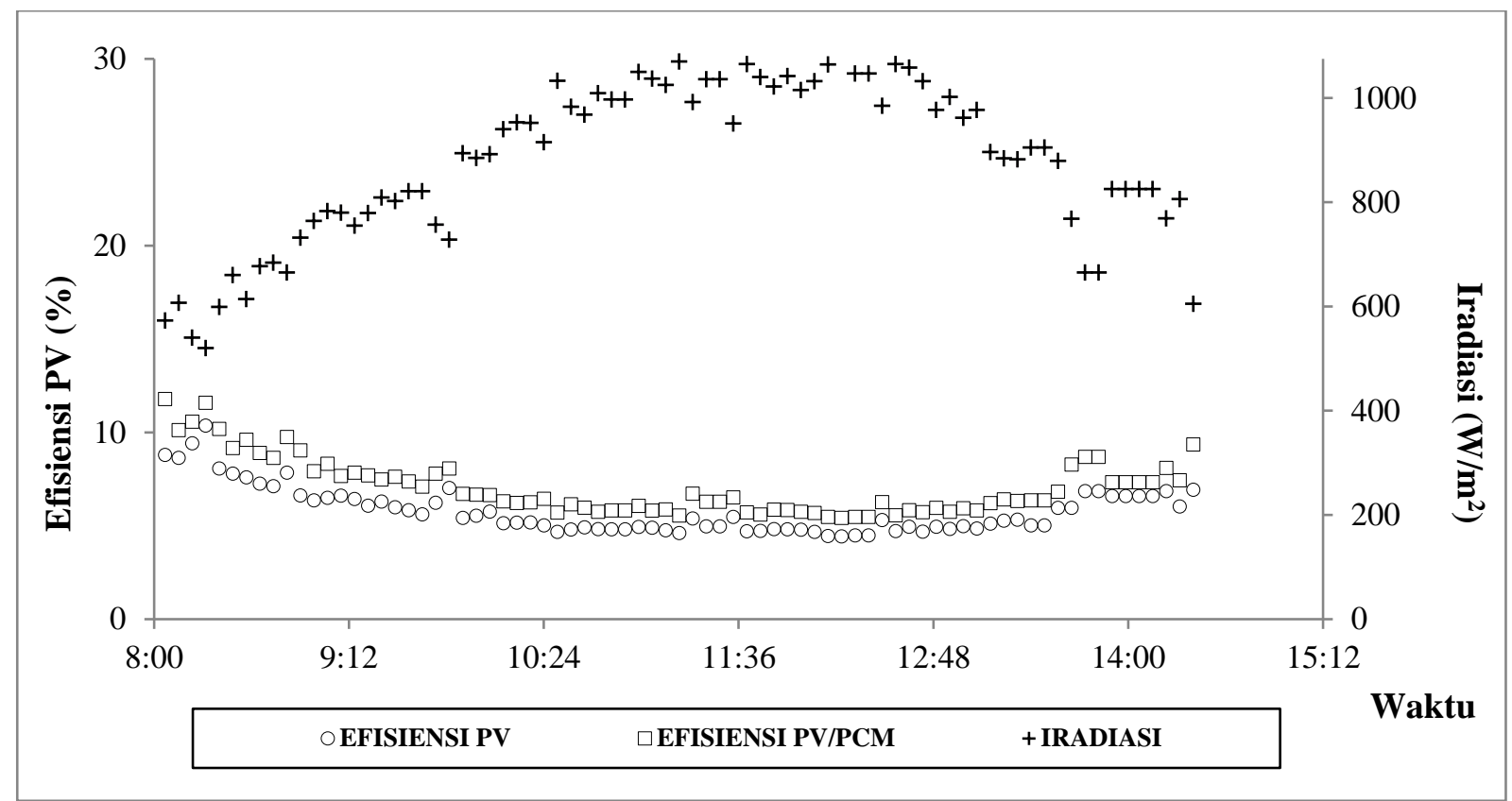

Gambar 8. Grafik efisiensi elektrik PV dan PV/PCM serta iradiasi matahari.

Penggunaan MPPT pada Modul surya B (tanpa menggunakan PCM) selalu menghasilkan daya yang lebih besar.hal ini disebabkan Modul surya B selalu menghasilkan tegangan keluaran sesuai dengan spesifikasi Modul surya yaitu pada interval 15,12 V - 21,87 V sedangkan Modul surya A yang tidak menggunakan MPPT selalu menghasilkan tegangan keluaran sesuai tegangan baterai yaitu 11,67 V 17,79 V. Penurunan iradiasi tidak terlalu berpengaruh pada tegangan keluaran Modul surya namun sangat berpengaruh pada arus keluaran Modul surya, hal ini diakibatkan karena adanya reverse bias dari efek photovoltaic. 


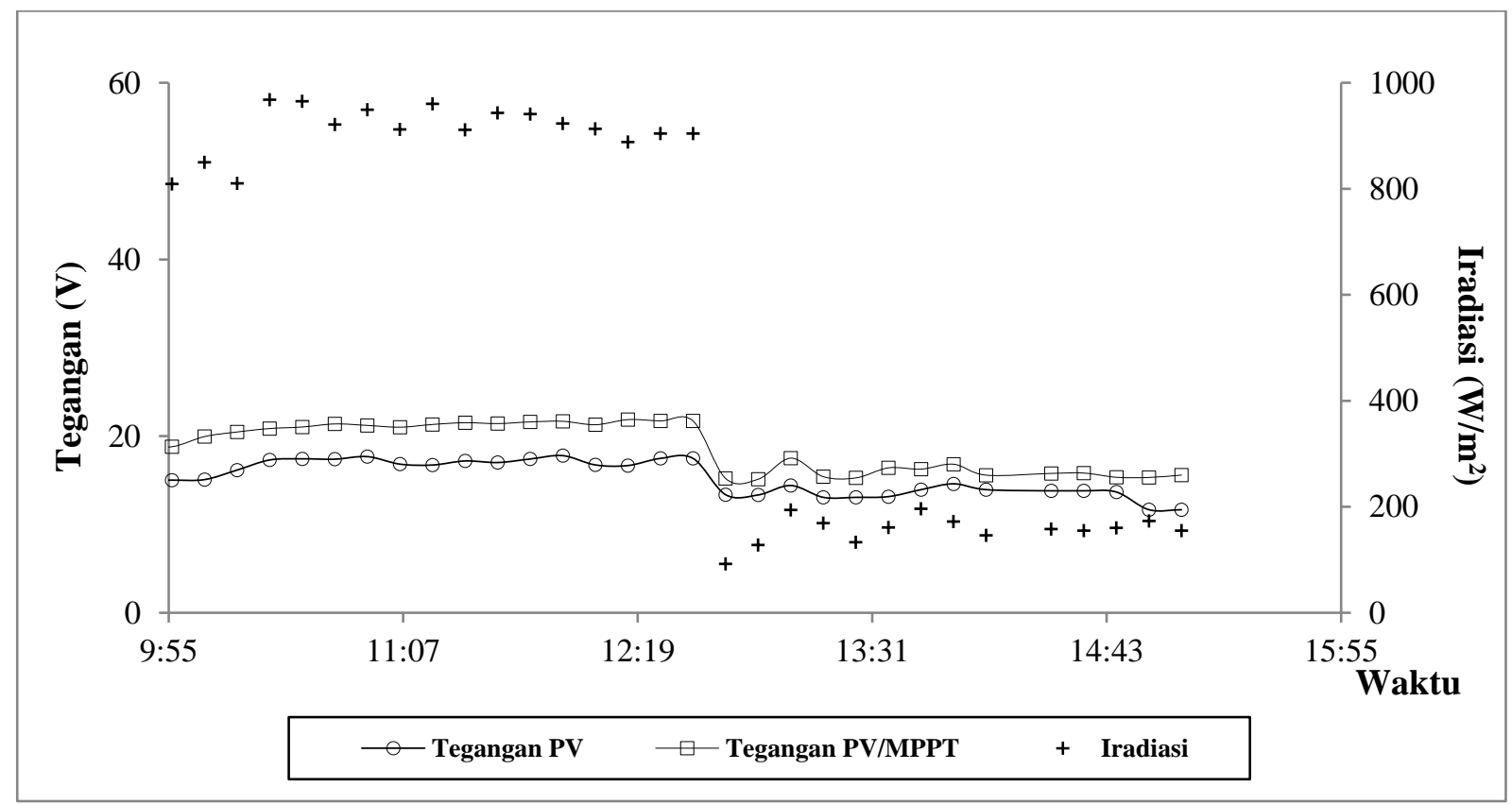

Gambar 9. Grafik tegangan PV dan PV/MPPT serta iradiasi matahari.

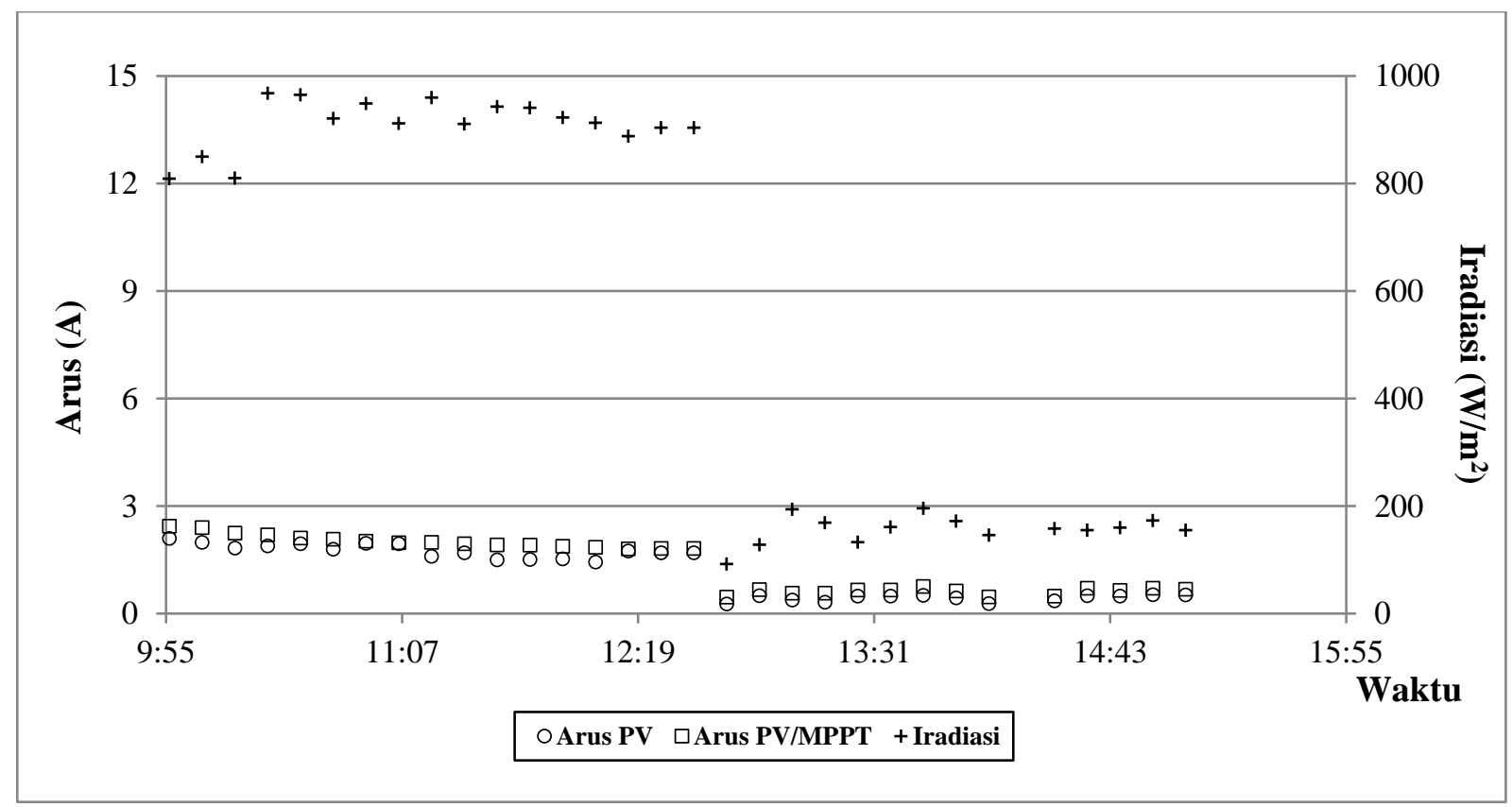

Gambar 10. Grafik arus PV dan PV/MPPT serta iradiasi matahari. 


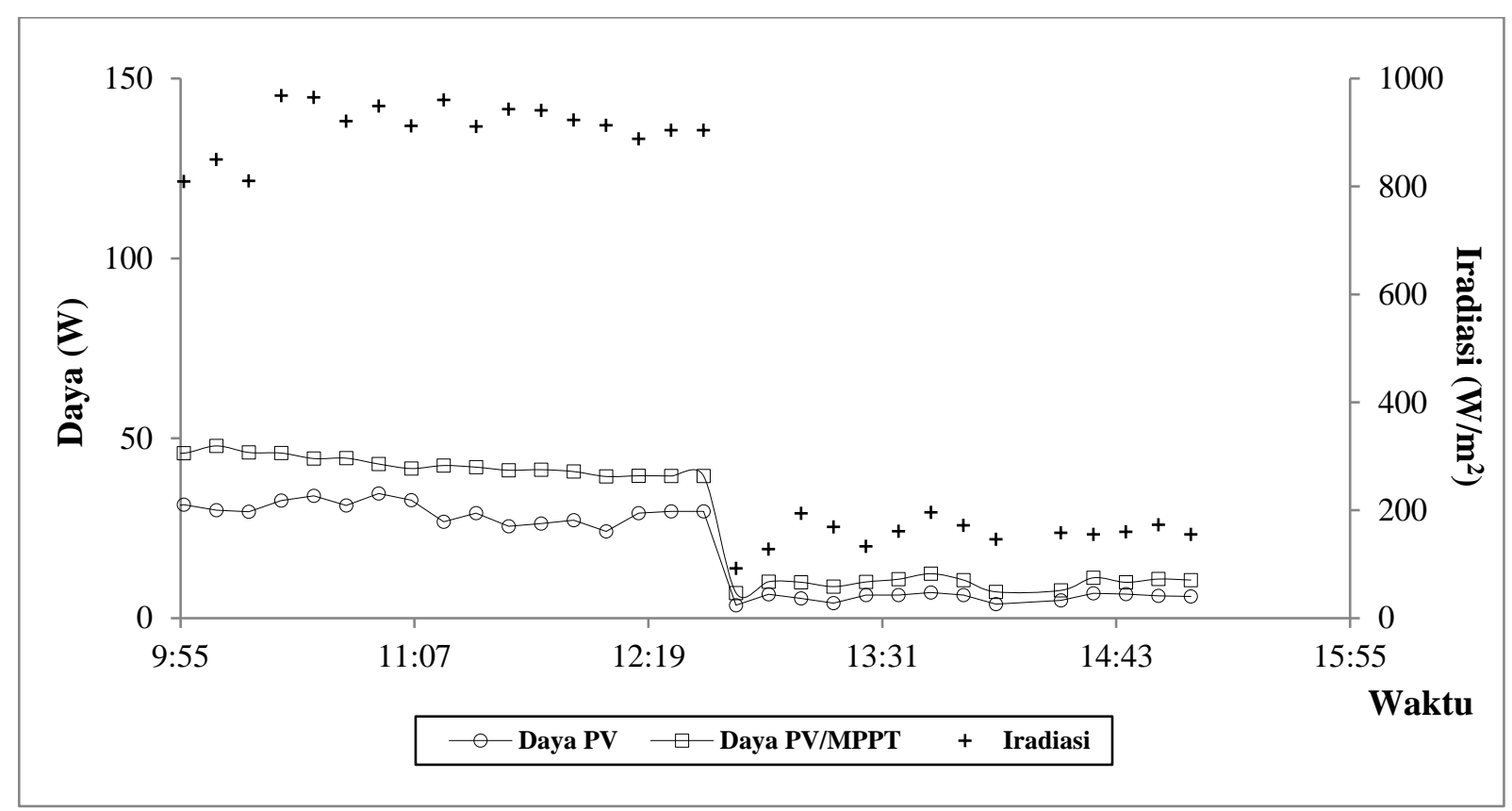

Gambar 11. Grafik daya PV dan PV/MPPT serta iradiasi matahari.

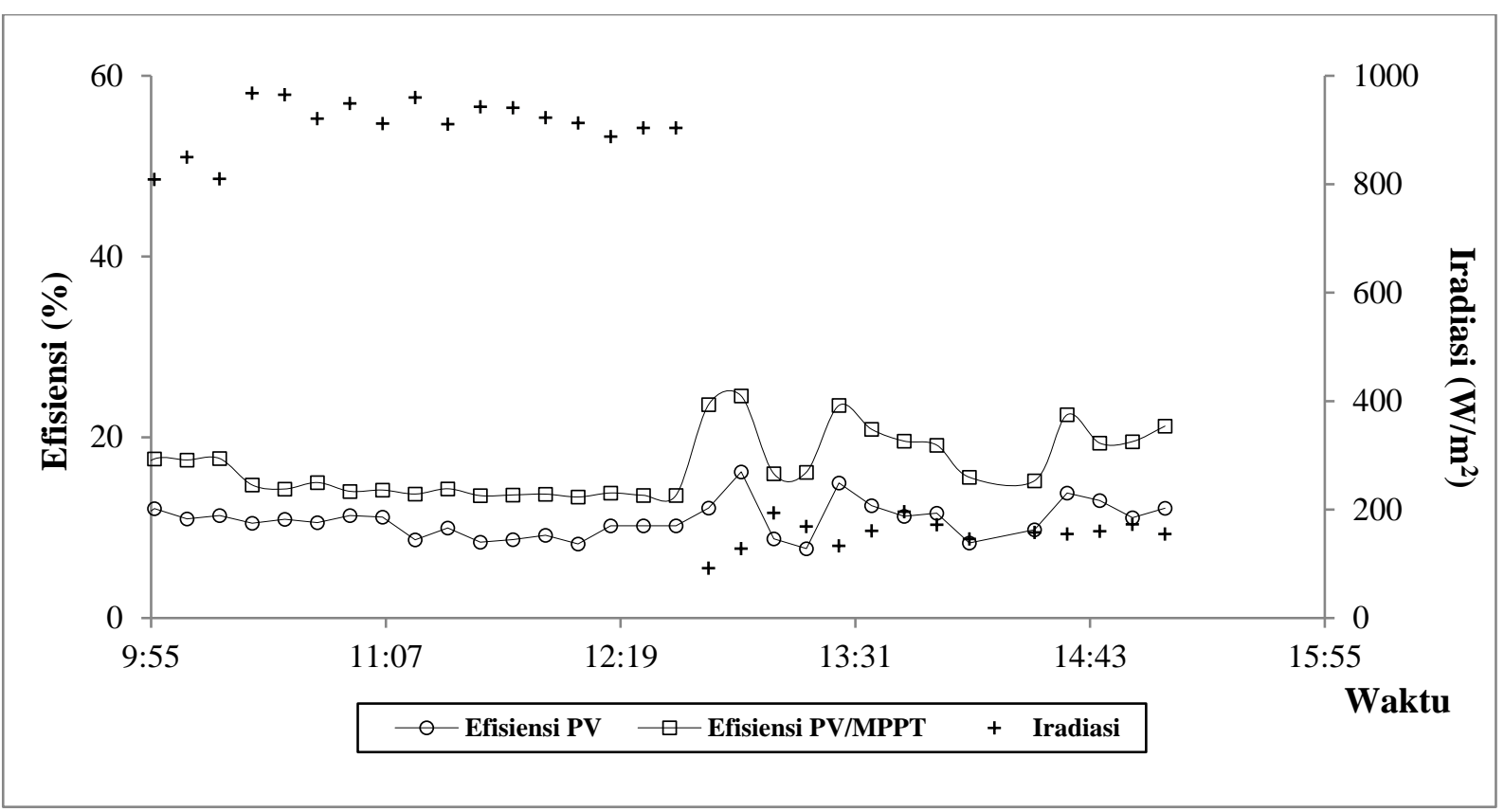

Gambar 12. Grafik efisiensi PV dan PV/MPPT serta iradiasi matahari.

Daya dan efisiensi modul PV/MPPT masih tinggi saat terjadinya penurunan iradiasi secara tiba-tiba dan berlangsung cepat disebabkan MPPT yang memungkinkan modul PV selalu bekerja pada kondisi optimumnya.

Pengujian Modul surya A dengan Modul surya B yang menggunakan PCM dan MPPT, Modul surya B selalu menghasilkan temperatur sel PV lebih rendah serta daya dan efisiensi elektrik yang lebih besar. Penurunan daya akibat terlambatnya respon PCM terhadap penurunan iradiasi tiba-tiba dan berlangsung sangat cepat mampu diantisipasi dengan menggunakan MPPT. 


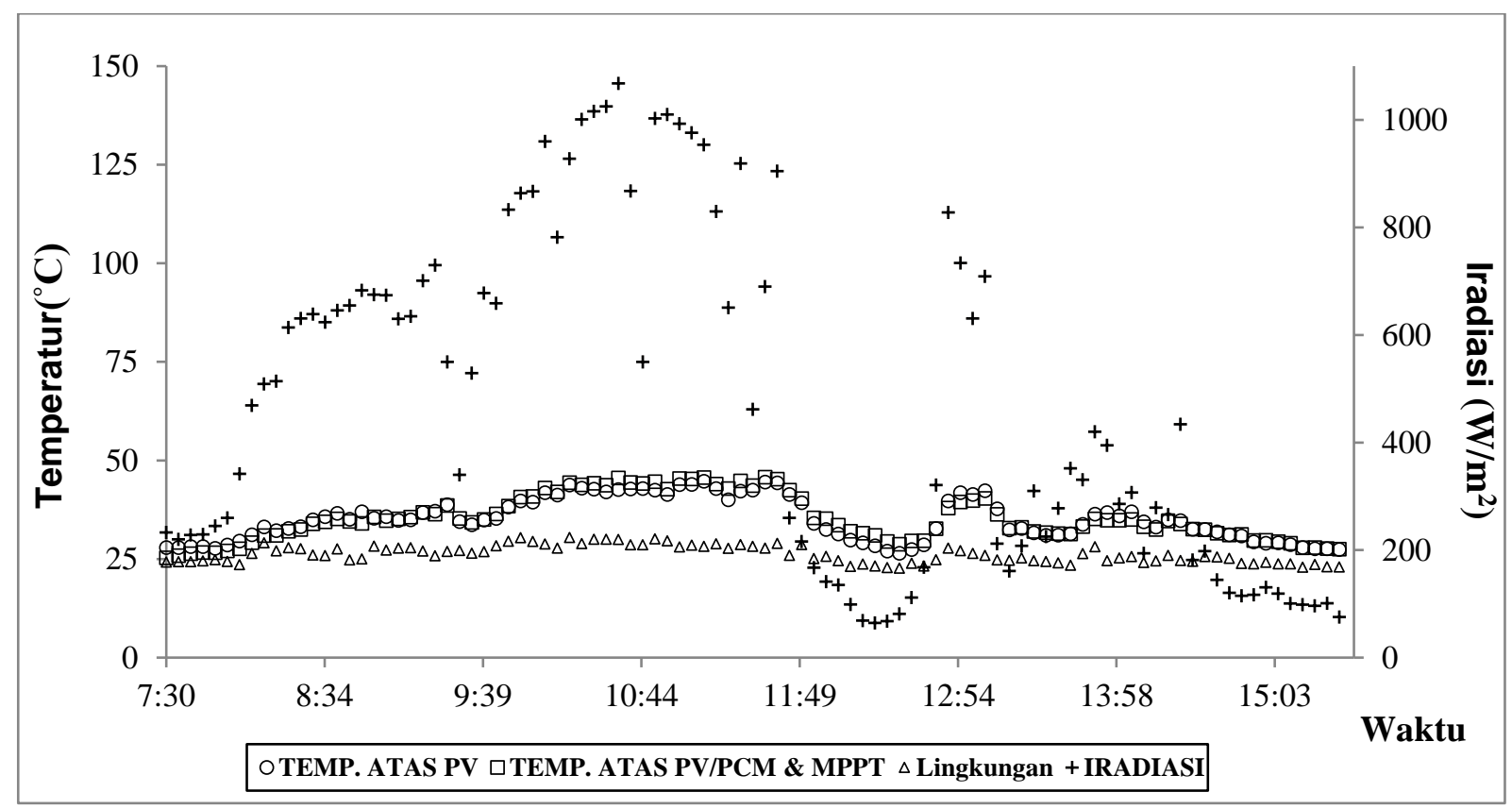

Gambar 13. Grafik temperature atas PV dan PV/PCM \& MPPT serta iradiasi matahari.

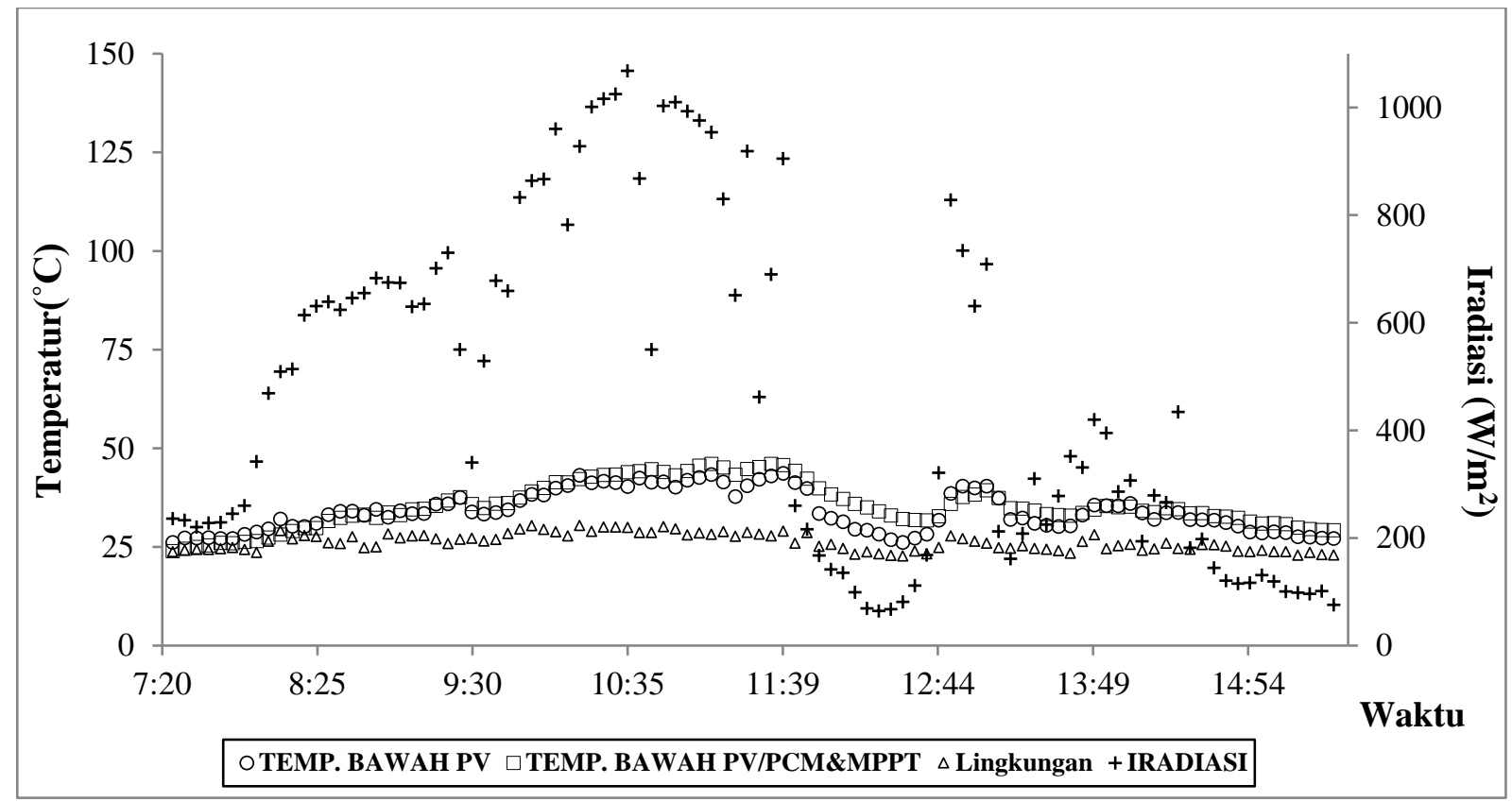

Gambar 14. Grafik temperature bawah PV dan PV/PCM \& MPPT serta iradiasi matahari. 


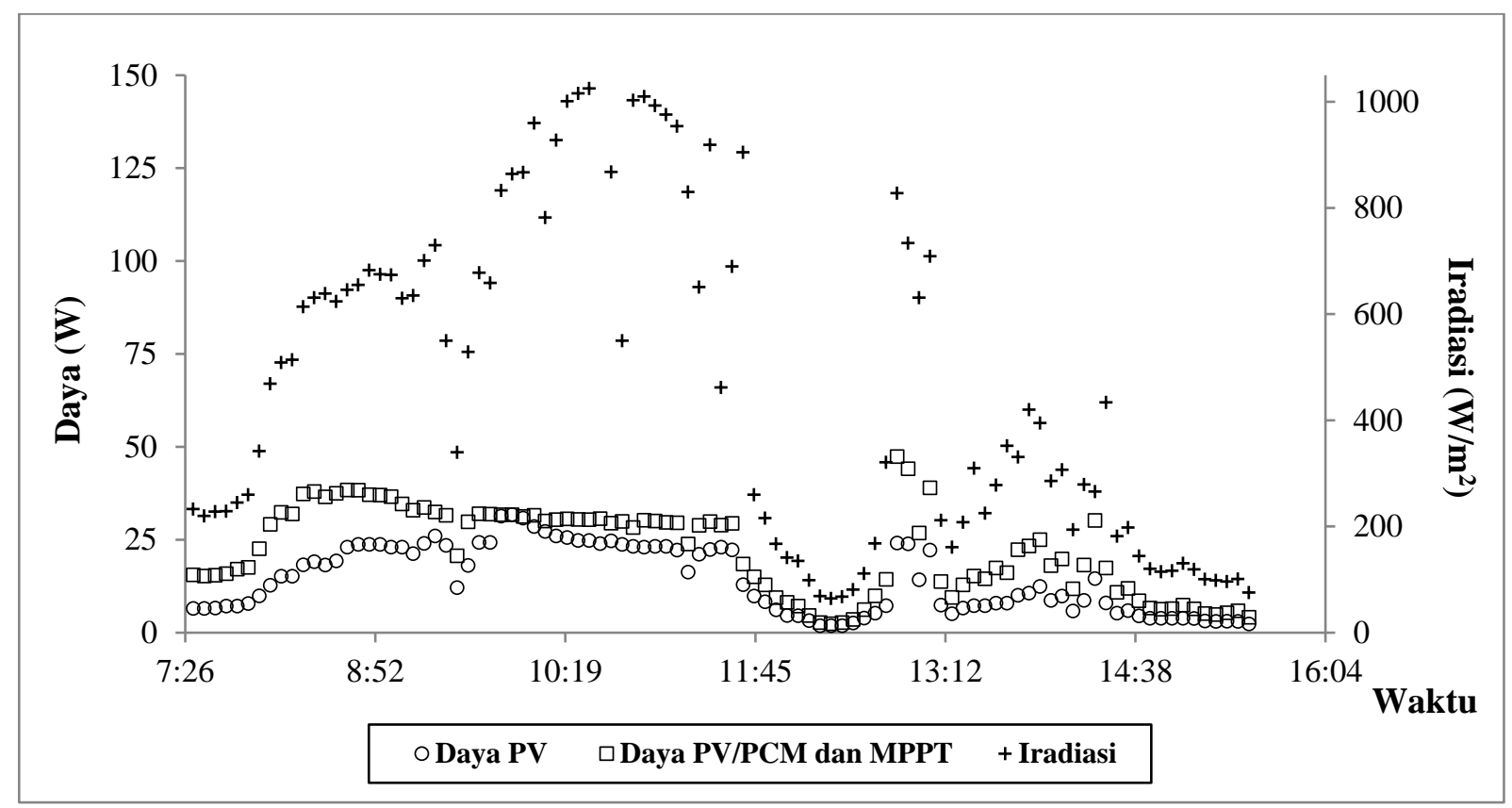

Gambar 15. Grafik daya PV dan PV/PCM \& MPPT serta iradiasi matahari.

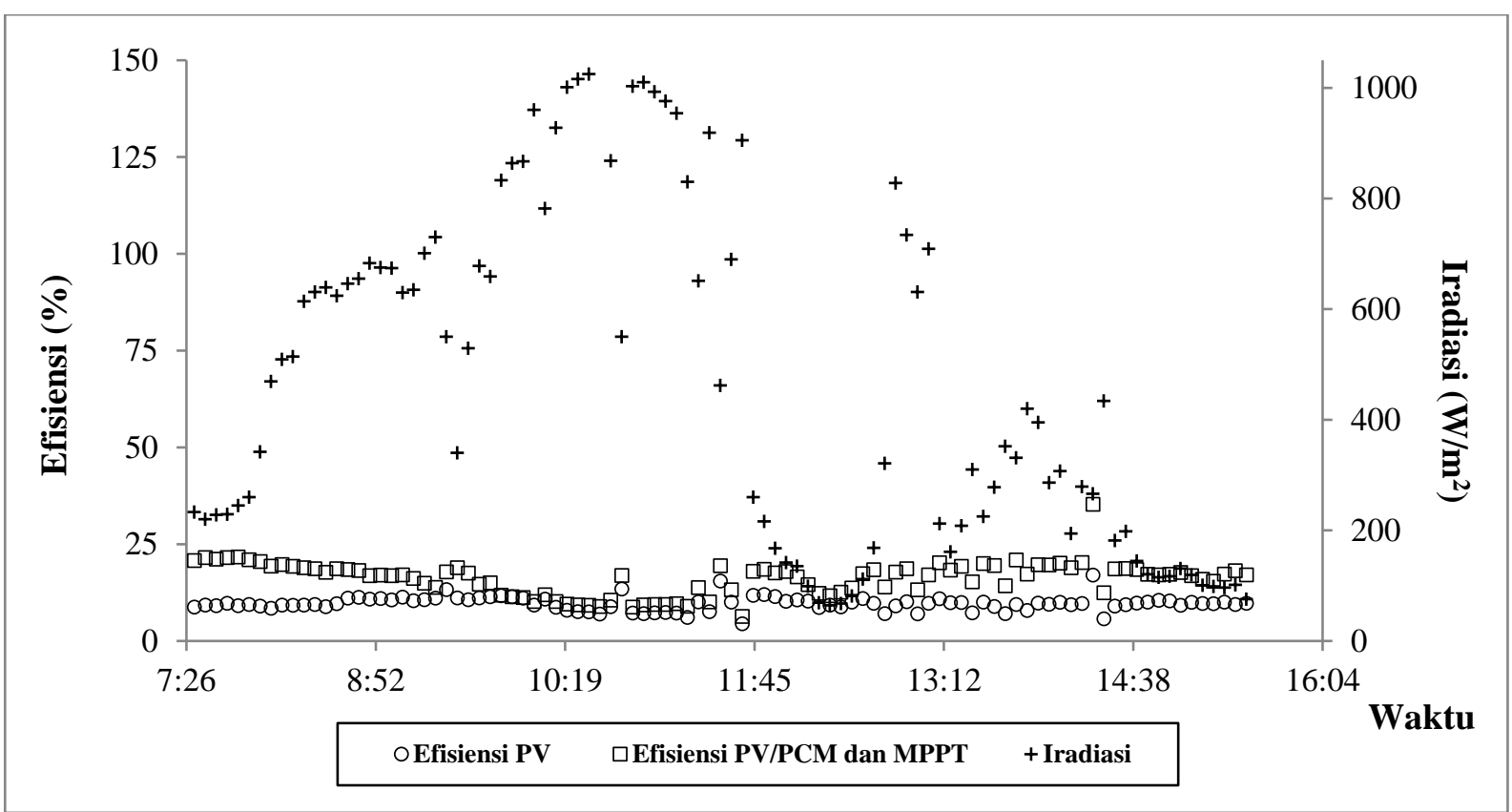

Gambar 16. Grafik efisiensi PV dan PV/PCM \& MPPT serta iradiasi matahari.

\section{KESIMPULAN}

Dari hasil pengujian dapat disimpulkan bahwa penggunaan MPPT pada Modul surya mampu meningkatkan efisiensi elektrik Modul surya rata-rata dari $10,71 \%$ menjadi $16,55 \%$. Daya elektrik meningkat dari $18,79 \mathrm{~W}$ menjadi $27,37 \mathrm{~W}$ dengan kenaikan daya rata-rata yang bisa dicapai sebesar 45,66\%. Penggunaan CPO sebagai PCM pada Modul surya mampu meningkatkan efisiensi elektrik Modul surya rata-rata dari $6,42 \%$ menjadi $7,72 \%$. Daya elektrik meningkat dari $14,78 \mathrm{~W}$ menjadi $17,87 \mathrm{~W}$ dengan kenaikan daya rata-rata yang bisa dicapai sebesar $20,94 \%$. 
Modul surya yang dilengkapi dengan MPPT dan juga menggunakan CPO sebagai PCM mampu menghasilkan peningkatan efisensi elektrik Modul surya rata-rata dari 9,64\% menjadi 16,27\% dengan kenaikan daya elektrik dari $14,12 \mathrm{~W}$ menjadi $22,02 \mathrm{~W}$ serta kenaikan daya rata-rata yang bisa dicapai sebesar 55,97\%. Penggunaan PCM dan MPPT secara bersama-sama pada Modul surya terbukti mampu meningkatkan efisiensi elektrik Modul surya secara signifikan dimana kombinasi CPO sebagai PCM mampu menurunkan temperatur sel PV pada saat iradiasi maksimum, namun reaksi akibat penurunan iradiasi tiba-tiba yang lambat di respon oleh PCM karena adanya inersia termal mampu diminimalisasi oleh komponen MPPT.

\section{Ucapan Terima Kasih}

Terima kasih disampaikan kepada Pusat Penelitian Energi Baru Terbarukan (PPEBT), Institut Teknologi Bandung serta para staf di dalamnya karena telah memberikan waktu, sarana dan prasarana selama penelitian berlangsung.

\section{DAFTAR PUSTAKA}

[1] Reinders, A.,Susandi, A.,Iswarayoga, N.,Sablerolle, T.,Veldhuis, H. (2012) : Solar Energy in Indonesia: Grid-Tied Photovoltaics for Electricity Supply on Islands, INDF Project Report, 3, International Solar Energy Conference, Bandung-Indonesia.

[2] Huang. MJ, P.C Eames, and B. Norton., (2003) : Thermal Regulation of Building-Integrated Photovoltaics Using Phase Change Material-International, Journal of Heat and Mass Transfer, 47, 2715.

[3] Laila, L., (2012) : Penambahan Bahan Berubah Fasa pada Batako sebagai Bahan Campuran Dinding Bangunan untuk Penghematan Energi pada Sistem Pengkondisian Udara, Makalah Tugas Akhir Sarjana, Institut Teknologi Bandung, Bandung-Indonesia.

[4] Wulandari, N., Tien, R., Muchtadi., Slamet, B., Sugijono., (2011) : Sifat Fisik Minyak Sawit Kasar dan korelasinya dengan Atribut Mutu, Institut Pertanian Bogor, Bogor-Indonesia. 